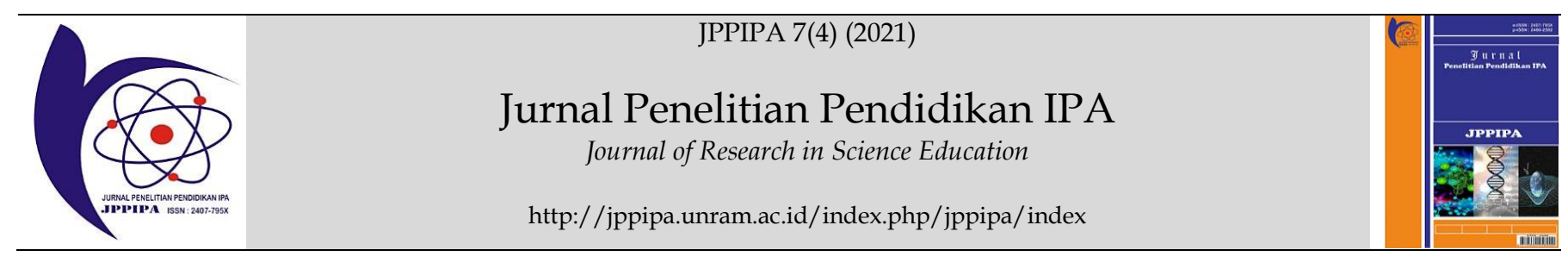

\title{
The Effect of Using the Student Academic Ability- Problem Solving and 5E Cycle Learning Models on the Student Learning Outcomes
}

\author{
Yayat Mutia Ardi*, Vauzia², Abdul Razak³, Syamsurizal ${ }^{4}$ \\ ${ }^{1}$ Biology Department, Faculty of Mathematics and Sciences, Universitas Negeri. Padang - 25131, Indonesia.
}

DOI: $\underline{10.29303 / j p p i p a . v 7 i 4.777}$

\section{Article Info}

Received : June 2nd, 2021

Revised : September 19th, 2021

Accepted: October 7th, 2021

\begin{abstract}
Education in the 21st century aims to change the learning paradigm from teachercentered to student-centered in order to improve student learning outcomes. Hence, a learning model is needed to improve the students' ability to solve problems by paying attention to their academic ability. This study aims to determine the effect of using the student academic ability-based problem solving and $5 \mathrm{E}$ cycle learning models on the student learning outcomes in addictive materials and addictive substances. This study used an experimental method with a $2 \times 2$ factorial design. The population in this study was all students of grade VIII SMPN 18 Padang. This study's sample was chosen using the purposive sampling technique, the data collection techniques for the student learning outcomes used to test techniques at the end of learning. The data analysis was performed by using the prerequisite tests (normality and homogeneity tests) and the hypothesis tests using 2-way ANOVA and continued with Bonferroni advanced test. The results show that: There is an interaction between the problem-solving model and the academic ability-based $5 \mathrm{E}$ Cycle learning model on the student learning outcomes, but there is no significant difference in learning outcomes between the problem-solving model and the 5E learning cycle model. There is an effect on the academic ability towards the student learning outcomes. There is no difference in the student learning outcomes between students with high academic ability in the two sample classes. There is no difference between the students with low academic ability in the two sample classes.
\end{abstract}

Keywords: Problem-solving; 5E learning cycle; learning outcomes; academic ability.

Citation: Ardi, Y., Vauzia, V., Razak, A., \& Syamsurizal, S. (2021). The Effect of Using the Student Academic AbilityProblem Solving and 5E Cycle Learning Models on the Student Learning Outcomes. Jurnal Penelitian Pendidikan IPA, 7(4), 607-611. doi:https:// doi.org/10.29303/jppipa.v7i4.777

\section{Introduction}

Education in the 21st century aims to change the learning paradigm from teacher-centered to studentcentered. This really depends on the teacher's readiness, ability, and creativity in applying various learning models. According to Sundari (2015) and Suyitno (2021), the learning model is a strategy used by teachers to improve student learning outcomes, social skills, and learning motivation. Based on the interview results, it was known that the science learning process at SMPN 18 Padang was still student-centered by applying the conventional learning model, namely the lecturing and question and answer method. As a result, students are less trained to think scientifically in formulating problems, analyzing, and drawing conclusions from learning. Thus, the problems that arise at the end of the learning process are the low learning outcomes of students. The low student learning outcomes are also influenced by the lack of teacher attention to different academic abilities for each student (Sari, 2020). The low learning outcomes of students can be seen from the mean results of PTS IPA Semester 2 Academic Year 2019/2020 in Table 1. 
Table 1. List of The Mean Results of PTS IPA Semester 2 Academic Year 2019/2020 of Grade VIII SMP N 18 Padang.

\begin{tabular}{llllll}
\hline No. & Classes & Total & $\begin{array}{l}\%< \\
\text { KBM }\end{array}$ & $\% \geq$ KBM & Mean \\
\hline 1. & VIII. 6 & 30 & 83.33 & 16.66 & 71.36 \\
2. & VIII. 7 & 31 & 90.32 & 9.67 & 64.22 \\
3. & VIII. 8 & 32 & 78.12 & 21.87 & 69.37 \\
4. & VIII. 9 & 31 & 80.64 & 19.32 & 70.48 \\
\hline
\end{tabular}

Based on the problems described, it is necessary to use an appropriate learning model to improve the student learning outcomes. One learning model that can be used is the problem-solving learning model. The problem-solving learning model is a student-centered learning model that can effectively train students to analyze a problem to improve student learning outcomes (Ardiansyah, 2017). In addition, the 5E learning cycle model can also improve student learning outcomes (Yunus, 2018). This is supported by Sugiantara 's (2013) research that the design of the $5 \mathrm{E}$ learning cycle model has steps that have implications for improving student learning outcomes because it is student-centered.

The problem-solving model and the 5E learning cycle learning model are basically almost similar. These two learning models aim to improve the thinking skills and learning outcomes of students. The syntax in these two learning models will train students to take an active role in learning activities (Mega, 2018). Learning materials that can be applied using both models are additives and addictive substances. This material is very important to be understood by students because it is informative and relates to the daily life of students. Based on these problems, the purpose of this study was to determine the comparison of using the Student Academic Ability-based Problem Solving and 5E Cycle Learning models on the student learning outcomes in addictive materials and additive substances at SMPN 18 Padang.

\section{Method}

This study used an experimental method with a $2 \times 2$ factorial design. The population in this study was all the students of grade VIII at SMP N 18 Padang registered in the 2019/2020 academic year. Class VIII.4 and VIII.2 were the samples of this study chosen by using the purposive sampling technique. Clearly, the problem-solving learning model was used in class VIII.4, and the 5E learning cycle model was used in class VIII.2. The type of data in this study was primary data. The technique of collecting data for learning outcomes used a test technique at the end of the lesson. The following formula calculated the students' scores:
Result $=\frac{\text { Score obtained }}{\text { Maximum score }} \times 100$

The research instrument of student learning outcomes was in the form of objective questions. Before the question instrument was used, a test question was conducted to determine the empirical validity, reliability, difficulty level, and distinguishing power of the questions. In this study, the reliability result of the test obtained was 0.94 with high criteria. Furthermore, the data analysis technique was carried out by means of prerequisite tests (normality and homogeneity tests) and hypothesis tests using 2-way ANOVA continued with Bonferroni advanced test by using the SPSS program.

\section{Result and Discussion}

The data description of the results of this study included the results of the students post-test using the students' academic ability-based problem-solving learning and the 5E Cycle learning models. Based on the student learning outcomes mean, the problemsolving model's application obtained higher learning outcomes than the 5E learning cycle model in Table 2.

Table 2. The Research Results of the Comparison of Using the Student Academic Ability-based Problem Solving and 5E Cycle Learning Model on the Student Learning Outcomes

\begin{tabular}{lllll}
\hline Classes & Mean & Academic Ability & Mean & SD \\
\hline VIII.4 & 82,00 & High & 90.25 & 4.83 \\
(Class 1) & & Low & 73.75 & 6,36 \\
VIII.2 & \multirow{2}{*}{79,60} & High & 84.53 & 8,26 \\
(Class 2) & & Low & 74.67 & 6.17 \\
\hline
\end{tabular}

The prerequisite test in this study was the normality and homogeneity test. The normality test in the study used the Kolmogorov-Sminor test. The normality test was used to determine whether the data obtained were normally distributed or not. The data was said to be normally distributed if the significance value was $>0.05$. The homogeneity test was carried out by using the Levene test. The homogeneity test was carried out to show that the two groups of sample data come from populations that have the same variant. The data was said to be homogeneous if the significance value was $>0.05$. The results of the normality and homogeneity test of student learning outcomes in the experimental class 1 and experimental class 2 with Sig> $a$, which means that the data is normally distributed and has a homogeneous variance, can be seen in Table 3. 
Table 3. The Results of Normality and Homogeneity Tests of the Student Learning Outcomes

\begin{tabular}{llll}
\hline \multirow{2}{*}{ Parameter } & \multicolumn{2}{l}{ Class } & \multirow{2}{*}{ Description } \\
\cline { 2 - 3 } & I & II & \\
\hline Normality & 0.17 & 0.20 & Normal \\
Homogeneity & 0.10 & Homogenous \\
Hypothesis (t test) & 0.32 & There is no difference \\
& & between the PS and LC \\
& & 5E models \\
\hline
\end{tabular}

After the prerequisite test results were obtained, the data analysis was continued with hypothesis testing using two-way ANOVA in Table 4. In the class parameters (model), the significance value was obtained $0.15>a(0.05)$. It means that there is no significant difference in learning outcomes between the application of the problem-solving learning model with the $5 \mathrm{E}$ learning cycle model. For the parameter of academic ability, a significance value was obtained 0.00 $<\alpha(0.05)$. It can be concluded that there is a significant difference in student learning outcomes between students with high academic ability and students with low academic ability. The interaction parameter between class (model) and academic ability shows a significance value of $0.04<a(0.05)$. This shows that there is an interaction between the learning model and academic ability on student learning outcomes in addictive and addictive substances. The interaction between the learning model and the student academic ability can be seen in (Figure 1)

Table 4. The Results of Two-Way Anova Test of Student Learning Outcomes and Academic Ability

\begin{tabular}{lllll}
\hline Parameter & $\begin{array}{l}\text { Mean } \\
\text { Square }\end{array}$ & F & Sig. & Description \\
\hline Class (Model) & 89,18 & 2,11 & 0,15 & $\begin{array}{l}\text { Not } \\
\text { significant } \\
\text { Academic }\end{array}$ \\
$\begin{array}{l}\text { Ability } \\
\text { Class* }\end{array}$ & 170,32 & 4,03 & 0,04 & $\begin{array}{l}\text { There is } \\
\text { interaction }\end{array}$ \\
$\begin{array}{l}\text { Academic } \\
\text { Ability }\end{array}$ & & 63,78 & 0,00 & Significant \\
\hline
\end{tabular}

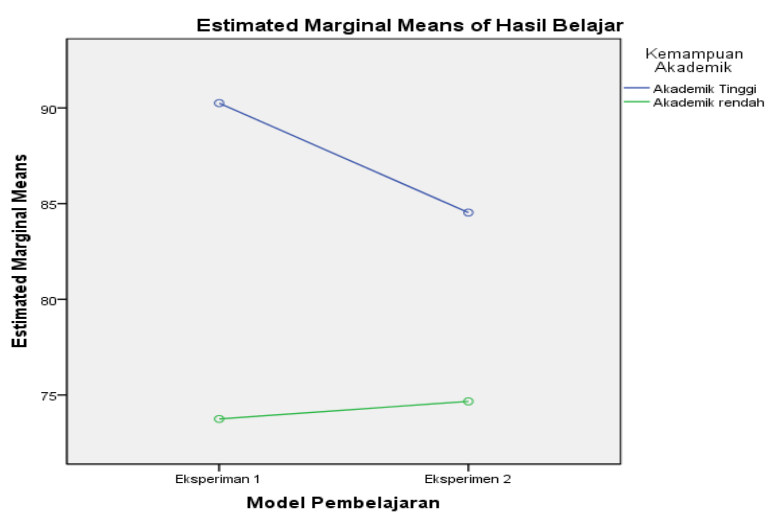

Figure 1. The interaction between the model and academic ability in the sample class.
Furthermore, the Bonferroni advanced test was carried out to determine which groups were significantly different. The results of the Bonferroni advanced test showed a significant difference in academic ability in the two sample classes, except in experimental class 1 with high academic ability, in experimental class 2 with high academic ability, in experimental class 1 with low academic ability, and in experimental class 2 with low academic ability. It can be seen in Table 5 .

Table 5. The results of the Bonferroni Advanced Test for the Student Academic Ability Group

\begin{tabular}{lllll}
\hline Ability & $\begin{array}{l}\text { Class I } \\
\text { KAT }\end{array}$ & $\begin{array}{l}\text { Class I } \\
\text { KAR }\end{array}$ & $\begin{array}{l}\text { Class II } \\
\text { KAT }\end{array}$ & $\begin{array}{l}\text { Class II } \\
\text { KAR }\end{array}$ \\
\hline $\begin{array}{l}\text { Class I } \\
\text { KAT }\end{array}$ & & & & \\
Class I & $16,50^{*}$ & & & \\
KAR & & & \\
Class II & 5,71 & $16,5^{*}$ & & \\
KAT & & & \\
Class II & $15,58^{*}$ & 0,91 & $9,86^{*}$ & \\
KAR & & & \\
\hline
\end{tabular}

Description: KAT: High academic ability KAR: Low academic ability

The learning process carried out during the research as a whole was in accordance with the steps of the problem-solving model and the $5 \mathrm{E}$ cycle learning model. In its application, the problem-solving learning model consists of 7 syntaxes: introduction, observation, initial problem, collecting data/information, organizing data, analyzing/generalizing data, and communicating (Alberida, 2018). The preliminary stage was the first stage which aims to motivate students and link the material to be studied with the experiences of students. The second stage was an observation which at this stage, students were asked to observe a picture or a discourse about additive and addictive substances contained in the student worksheet. According to Ong (2021), observing, asking, and predicting are the basic abilities that students must have. The third stage is the initial problem. In this stage, questions from students will appear after making observations, and students will be able to provide hypotheses or temporary answers from the images or discourse that have been provided.

The fourth stage is collecting data and information. At this stage, students will collect data through group discussion activities to increase their understanding of the material being studied. Students who are active in learning activities have an impact on improving student learning outcomes (Ardiansyah, 2018). The next stage was organizing data and analyzing data. At this stage, students process the information that has been collected in the previous 
stage. This activity aims to develop ideas that students have. At this stage, students are required to think actively, both individually and in groups, to analyze a problem to be solved (Hera, 2018).

The next stage was communication, where at this stage, a question-and-answer discussion is carried out. This stage was able to build the activeness of students in giving and answering questions related to a problem. Communicating the results of learning activities will expand students' understanding of the learning material and, through this activity, can provide evidence that students have understood the learning material. Meanwhile, the 5E Cycle Learning model has five syntaxes: Engagement, Exploration, Explanation, Elaboration, and Evaluation (Rosidi and Muslim. 2015). The first stage is engagement. At this stage, the teacher tries to arouse students' interest in learning by explaining the importance of additive and addictive substances. According to (Asriyadin, 2016) arousing students 'interest in learning can be done by asking questions, an overview of the material to be studied, or other activities that are used to open knowledge and develop students' curiosity. The engagement phase aims to prepare students to be conditioned to take the next phase (Latifa, 2017).

The second stage is an exploration where at this stage, students are emphasized to work together with group members consisting of 2-6 students. This stage can be done by observing, asking, and investigating the concepts of the learning materials that have been provided (Asriyadin, 2016). The third stage is an explanation, where at this stage, the teacher encourages students to be able to explain a concept in their own sentences along with the evidence of the explanation. In line with Asriyadin opinion (2016), the explanation phase contains an invitation or encouragement for students to explain the initial concepts and definitions they get using their own sentences.

The fourth stage is elaboration. At this stage, students are emphasized to solve new problems based on the new knowledge that students have acquired. This stage aims to bring students to use the definitions, concepts, and skills that students already have in new situations. At this stage, students will develop concepts and skills in new situations (Latifa, 2017). This phase can include investigation, problem-solving, and making decisions (Asriyadin, 2016). The fifth stage is an evaluation where students and the teacher evaluate the learning that has been done at this stage. The evaluation stage is the stage of assessing all learning and teaching. According to Latifa (2017), the teacher assesses whether students have achieved the learning objectives at this evaluation stage.

There was no significant difference in the student learning outcomes between the problem-solving learning model and the 5E cycle learning model in additive materials and addictive substances that can be influenced by internal and external factors such as student learning experiences, learning motivation, and learning materials and learning time. This was in accordance with the results of the studies conducted by Apriyani (2017); Dewi (2021); Sojanah (2021); Soenarto (2020), and Madjid (2021), who argued that student learning outcomes are also influenced by external factors such as the learning environment, facilities and infrastructure, preparation, teacher TPACK (Technological Pedagogical and Content Knowledge), and the length of teacher experience in teaching. In addition, students' learning outcomes were also influenced by the students' psychological factors, learning methods, and abilities. Although this study found that the average learning outcomes of students who applied the problem-solving learning model were higher than the $5 \mathrm{E}$ cycle learning model, in practice, these two learning models were able to increase the students' activeness in analyzing and solving a problem. The stages in the problem-solving learning model and the 5E cycle learning model make students play an active role in the learning process because these two learning models were student-centered.

\section{Conclusion}

Based on the study results that have been done, it can be concluded that there was an interaction between the problem-solving model and the 5E Cycle learning model with academic ability on the student learning outcomes. However, there was no significant difference in learning outcomes between the problem-solving and $5 \mathrm{E}$ cycle learning models. There was an effect of the academic ability on student learning outcomes; There was no difference in student learning outcomes between high academic ability in the two sample classes. There was no difference in low academic ability in the two sample classes.

\section{References}

Alberida, H., Lufri, Festiyed, \& Barlian, E. (2018). Problem Solving Model for Science Learning. IOP Conference Series: Materials Science and Engineering, 335(1). $\quad$ https://doi.org/10.1088/1757$\underline{899 X / 335 / 1 / 012084}$

Apriyani, L., Nurlaelah, I., \& Setiawati, I. (2017). Penerapan Model PBL untuk Meningkatkan Keterampilan Berpikir Kritis Ditinjau dari Kemampuan Akademik Siswa pada Materi Biologi. Jurnal Quagga. 9 (1): 41-54. DOI: https://doi.org/10.25134/quagga.v9i01.509 [Indonesian] 
Ardiansyah, R., Gading, I. K., \& Pudjawan, K. (2017). Pengaruh Model Pembelajaran Problem Solving terhadap Hasil Belajar IPA Siswa SD. e-Journal PGSD Universitas Pendidikan Ganesha. 5 (2): 1-11. doi: http://dx.doi.org/10.23887/jipgsd.v5i2.10890 [Indonesian]

Asriyadin., Yus'iran., \& Fikri, H. N. (2016). Pengaruh Model Learning Cycle 5E terhadap Hasil Belajar Fisika Siswa Kelas X SMAN 1 Madapangga Tahun Pelajaran 2016/2017. Jurnal Pendidikan MIPA. Vol. 6 (2): 63-67. Retrieved from http://ejournal.tsb.ac.id/index.php/jpm/article/ view/34 [Indonesian]

Dewi, A. (2021). Curriculum Reform In The Decentralization Of Education In Indonesia: Effect On Students' Achievements. Cakrawala Pendidikan, 40(1),

158-169. doi:https://doi.org/10.21831/cp.v40i1.33821

Hera, R. (2018). Pengaruh Model Pembelajaran Problem Solving terhadap Hasil Belajar Siswa pada Materi Pencemaran Lingkungan Kelas Kelas X SMAN 1 Beutong Kabupaten Nagan Raya. Genta Mulia. 9 (1): 147-156. https://ejournal.stkipbbm.ac.id/index.php/gm/a rticle/view/151/139 [Indonesian]

Latifa, B., Verawati, N., \& Harjono, A. (2017). Pengaruh Model Learning Cycle 5E (Engage, Explore, Explain, Elaboration, \& Evaluate) Terhadap Kemampuan Berpikir Kritis Peserta Didik Kelas X MAN 1 Mataram. Jurnal Pendidikan Fisika dan Teknologi, 3(1), 61-67. doi:http://dx.doi.org/10.29303/jpft.v3i1.325 [Indonesian]

Madjid, A., Sutoyo, D., \& Shodiq, S. (2021). Academic Procrastination Among Students: The Influence Of Social Support And Resilience Mediated By Religious Character. Cakrawala Pendidikan, 40(1), 56-69.

doi:https:// doi.org/10.21831/cp.v40i1.34641

Mega, W., Mulyani, W. S., \& Utomo, S.B. (2018). Pengaruh Model Pembelajaran Problem Solving dan Learning Cycle 5E terhadap Prestasi Belajar Ditinjau dari Kemampuan Metakognisi Siswa. Jurnal Penelitian Pendidikan. 21 (2): 186-202. doi: https://doi.org/10.20961/paedagogia.v21i2.23494 [Indonesian]

Ong, E., Govindasamy, D., Swaran Singh, C., Ibrahim, M., Abdul Wahab, N., Borhan, M., \& Tho, S. (2021). The 5e Inquiry Learning Model: Its Effect On The Learning Of Electricity Among Malaysian Students. Cakrawala Pendidikan, 40(1), 170-182. doi:https://doi.org/10.21831/cp.v40i1.33415

Rosidi, A., \& Muslim, S. (2015). Pengaruh Penerapan Model Pembelajaran Learning Cycle 5E terhadap Hasil Belajar Siswa pada Standar Kompetensi
Memasang Instalasi Penerangan Listrik. Jurnal Pendidikan Teknik Elektro. 4(1): 161-169. Retrieved from:

https://jurnalmahasiswa.unesa.ac.id/index.php/ 17/article/view/10409 [Indonesian]

Sari, S., \& Suryani, A. (2020). Accounting Students' Academic Performance by Their Background Information. Jurnal Ilmu Pendidikan, 26(2), 54-61. doi:http://dx.doi.org/10.17977/um048v26i2p54$\underline{61}$

Soenarto, S., Sugito, S., Suyanta, S., Siswantoyo, S., \& Marwanti, M. (2020). Vocational And Senior High School Professional Teachers In Industry 4.0. Cakrawala Pendidikan, 39(3), 655-665. doi:https://doi.org/10.21831/cp.v39i3.32926

Sojanah, J., Suwatno, S., Kodri, K., \& Machmud, A. (2021). Factors Affecting Teachers' Technological Pedagogical And Content Knowledge (A Survey on Economics Teacher Knowledge). Cakrawala Pendidikan, 40(1), 1-16. doi:https://doi.org/10.21831/cp.v40i1.31035

Sugiantara, I. P., Kusmariyatni, N., \& Margunayasa, I. G. (2013). Pengaruh Model Pembelajaran Learning Cycle 5E Terhadap Hasil Belajar Ipa Siswa Kelas V Di Gugus Vii Kecamatan Buleleng. MIMBAR PGSD Undiksha, 1(1). Retrieved from: https:// ejournal.undiksha.ac.id/index.php/JJPGS $\mathrm{D} /$ article/view/673 [Indonesian]

Sundari, H. (2015). Model-Model Pembelajaran dan Pemefolehan Bahasa Kedua/Asing. Jurnal Pujangga. $1 \quad$ (2): 106-117. doi: http://dx.doi.org/10.47313/pujangga.v1i2.321 [Indonesian] 